\title{
Analisis Penambahan Kunyit (Curcuma longa L) Terhadap Kadar Asam Lemak Bebas Pada Minyak Goreng Kelapa
}

\author{
${ }^{1}$ Angga Tritisari, ${ }^{2}$ Maslan \\ ${ }^{1}$ Jurusan AGRIBISNIS, Prodi AGROINDUSTRI PANGAN, Politeknik Negeri Sambas \\ ${ }^{2}$ Jurusan AGRIBISNIS, Prodi AGROINDUSTRI PANGAN, Politeknik Negeri Sambas \\ Kawasan Pendidikan Jalan Raya Sejangkung Kabupaten Sambas,Kalimantan Barat 79462 \\ 1ritisariangga@gmail.com
}

\begin{abstract}
ABSTRAK
Tujuan dari penelitian ini yaitu untuk mengetahui pengaruh waktu penambahan kunyit terhadap kadar asam lemak bebas minyak goreng kelapa. Minyak goreng adalah salah satu kebutuhan pokok manusia yang berfungsi sebagai media penghantar panas dalam pengolahan bahan pangan untuk memperbaiki warna, cita rasa dan tekstur dari makanan. Pembuatan minyak goreng kelapa menggunakan metode pemanasan. Namun, metode pemanasan dapat merusak antioksidan dalam minyak goreng kelapa. Akibat dari rusaknya antioksidan dapat meningkatkan kadar asam lemak bebas pada minyak goreng kelapa. Sehingga ditambahkan kunyit dalam pembuatan minyak goreng kelapa untuk menggantikan senyawa antioksidan yang rusak. Penelitian ini mengunakan tiga perlakuan yaitu perlakuan pertama pembuatan minyak goreng kelapa tanpa penambahan kunyit, perlakuan kedua penambahan kunyit sebanyak \pm 3 gram waktu titik akhir pemanasan dan perlakuan ketiga penambahan kunyit sebanyak \pm 3 gram waktu minyak dalam suhu ruang. Minyak goreng kelapa yang dihasilkan diuji kadar asam lemak bebas dengan metode titrasi asam basa pada minyak baru dan minyak setelah disimpan selama 1 bulan. Hasil uji kadar asam lemak bebas menunjukkan kadar tertinggi pada perlakuan pertama ulangan 1 dan 2 sebesar 0,0833\% dan $0,0878 \%$. Setelah disimpan selama 1 bulan meningkat menjadi 0,1181\% dan 0,1173\%. Sedangkan perlakuan kedua ulangan 1 dan 2 sebesar 0,0665\% dan 0,0661\%. Setelah disimpan 1 bulan kadar asam lemak bebasnya tidak mengalami perubahan yaitu sebesar 0,0656\% dan 0,0652\%. Pada perlakuan ketiga ulangan 1 dan 2 sebesar 0,0659\% dan 0,0653\%. Setelah disimpan selama 1 bulan meningkat menjadi 0,0859\% dan 0,0858\%. Hasil uji Ansira atau uji F menunjukkan setiap perlakuan percobaan waktu penambahan kunyit dalam pembuatan minyak goreng kelapa berpengaruh sangat nyata terhadap kadar asam lemak bebas minyak goreng kelapa.
\end{abstract}

Kata kunci: Antioksidan, asam lemak bebas, kunyit, minyak goreng.

\section{PENDAHULUAN}

Kelapa merupakan salah satu komoditi hasil perkebunan yang sangat penting dalam menunjang perekonomian Indonesia. Ini dapat dilihat dari besarnya ekspor yang dilakukan setiap tahunnya selalu mengalami peningkatan. Pada tahun 2010 Indonesia telah mengekspor kelapa sebanyak 1.045.317 ton, tahun 2011 sebanyak 1.199 .752 ton dan tahun 2012 sebanyak 1.651.624 ton (Direktorat Jendral Perkebunan, 2014). Salah satu sentra produksi kelapa di Indonesia yaitu Provinsi Kalimantan Barat. Pada tahun 2017 produksi kelapa di Kalimantan Barat mencapai 81.491 ton (Disbun Kalbar, 2018). Masyarakat Kalbar biasanya memanfaatkan buah kelapa sebagai bahan baku pengolahan minyak goreng.

Minyak goreng adalah salah satu kebutuhan pokok manusia sebagai alat pengolahan bahan makanan. Minyak goreng berfungsi sebagai media penghantar panas dalam pengolahan bahan pangan untuk memperbaiki warna, cita rasa dan tekstur dari makanan. Sebagai bahan pokok manusia tentunya diperlukan minyak goreng yang bermutu dalam pengolahan makanan. Standar mutu minyak goreng telah diatur dalam SNI 01 37422002 dengan kriteria bau, warna dan rasa normal khas minyak goreng, kadar air 0,30\%; asam lemak bebas 0,30\%; angka peroksida 1 mg (BSN, 2002). Jenis-jenis minyak goreng yaitu minyak sawit, minyak zaitun, minyak jagung, minyak kanola, VCO dan minyak goreng kelapa. Dari berbagai jenis minyak goreng tersebut yang sering digunakan masyarakat, khususnya di Provinsi Kalimantan Barat adalah minyak goreng kelapa.

Minyak goreng kelapa dibuat menggunakan buah kelapa yang sudah tua. Buah kelapa tua memiliki ciri-ciri yaitu kulit buah berwarna coklat dan bila buah diguncang akan mengeluarkan bunyi. Kandungan minyak pada kelapa tua cukup besar hingga $50 \%$. 
Pengolahan minyak goreng kelapa ini menggunakan cara sederhana atau tradisional yaitu dengan daging kelapa diparut untuk diambil santannya kemudian difermentasi dan diolah menggunakan metode pemanasan hingga blondo bewarna kuning kecoklatan. Metode pemanasan yang digunakan dapat merusak antioksidan dan asam lemak rantai sedang dalam minyak goreng kelapa. Akibatnya minyak goreng kelapa mengalami penurunan kualitas yang ditandai dengan meningkatnya kadar asam lemak bebas.

Asam lemak bebas atau free fatty acid (FFA) merupakan hasil degradasi dari triglisarida sebagai akibat dari kerusakan minyak. Terbentuknya FFA karena proses oksidasi dan hidrolisis selama pengolahan dan penyimpanan. Tingginya kadar FFA membuat minyak goreng berbau tengik. Terlalu sering mengkonsumsi makanan yang mengandung asam lemak bebas tinggi akan berbahaya bagi tubuh. Kadar asam lemak bebas yang tinggi akan bersifat toksik di dalam tubuh (Kumalasari, 2012). Untuk menghambat peningkatan kadar FFA pada minyak goreng dapat dilakukan dengan menambahkan senyawa antioksidan.

Antioksidan didefinisikan sebagai senyawa yang dapat menunda, memperlambat dan mencegah proses oksidasi lipid. Sumbersumber antioksidan dapat dikelompokkan menjadi dua, yaitu antioksidan sintetik dan antioksidan alami. Antioksidan sintetik yaitu antioksidan yang diperoleh dari hasil sintesa reaksi kimia. Antioksidan sintetik contohnya Butil hidroksi anisol (BHA), Butil hidroksi toluen (BHT), Tert-butil hidoksi quinon (TBHQ) dan tokoferol. Antioksidan alami adalah antioksidan hasil dari ekstraksi bahan alami. Antioksidan alami ditemukan pada buah, sayur dan umbi-umbian yang mengandung vitamin $\mathrm{A}$, vitamin $\mathrm{C}$, vitamin $\mathrm{E}$, gluten, enzim SOD (Super oksida dismutase) dan enzim katalase. Jenis tanaman yang memiliki kandungan antioksidan alami diantaranya kubis, wortel, mentimun, cabe, bayam, bawang, nanas, pepaya, jeruk, pisang, jahe kencur, asam jawa, kunyit dan lain-lain. (Prett, 1992 dalam Duni 2009). Tanaman yang mengandung senyawa antioksidan tinggi yaitu kunyit.

Kunyit merupakan tanaman herbal yang banyak ditemukan di Indonesia. Kunyit memiliki senyawa antioksidan tinggi yang dapat menghambat terjadinya oksidasi pada minyak. Namun, pada suhu tinggi antioksidan akan mudah rusak (Purba dkk, 2009). Dari uraian diatas, maka dilakukan penelitian tentang pengaruh waktu penambahan kunyit terhadap asam lemak bebas pada minyak goreng kelapa

\section{METODE}

Jenis penelitian yang dilakukan dalam penelitian ini adalah penelitian kualitatif kuantitatif. Metode pengumpulan data yang dilakukan adalah dengan melakukan observasi, percobaan laboratorium dan studi dokumentasi. Data observasi meliputi pengamatan buah kelapa yang akan digunakan, kunyit yang akan digunakan hingga pembuatan minyak goreng kelapa. Utk percobaan lapboratorium, miyak goreng kelapa yang telah dibuat dengan tiga perlakuan masing-masing diberikan kode sampel, selanjutnya dilakuakn pengujian kadar asam lemak bebas dengan metode titrasi asam basa

Data yang diperoleh akan diolah dengan menggunakan rancangan percobaan yaitu rancang Acak lengkap ( RAL ). Sebelum dilakukan pengujian kadar asam lemak bebas pada setiap sampel, terlebih dilakukan pengkodean. Setiap sampel uji dilakukan pengkodean yaitu ALB1 untuk perlakuan 1, ALB2 untuk perlakuan 2 dan ALB 3 untuk perlakuan 3. Untuk ulangan pengujian diberi kode U1 untuk ulangan 1, U2 untuk ulangan 2, U3 untuk ulangan 3 dan U4 untuk ulangan 4. Selanjutnya, data hasil uji kadar asam lemak bebas ditabulasi ke tabel analisis data rancang acak lengkap (RAL) sesuai dengan kode. Tabulasi data dengan RAL seperti tabel berikut ini:

Tabel 1. Tabulasi Data dengan RAL

\begin{tabular}{|l|l|l|l|l|}
\hline \multirow{2}{*}{$\begin{array}{c}\text { Kode } \\
\text { Sampel }\end{array}$} & \multicolumn{4}{|c|}{ Pengulangan } \\
\cline { 2 - 5 } & 1 & \multicolumn{1}{|c|}{2} & \multicolumn{1}{c|}{3} & \multicolumn{1}{c|}{4} \\
\hline ALB1 & ALB & ALB & ALB & ALB \\
& $1 U 1$ & $1 U 2$ & $1 U 3$ & $1 U 4$ \\
\hline ALB2 & ALB & ALB & ALB & ALB \\
& 2U1 & 2U2 & 2U3 & 2U4 \\
\hline ALB3 & ALB & ALB & ALB & ALB \\
& $3 U 1$ & $3 U 2$ & $3 U 3$ & $3 U 4$ \\
\hline
\end{tabular}

Data penelitian kuantitatif yang dikumpulkan melalui kegiatan lapangan pada dasarnya masih berupa data mentah. Untuk dapat menggunakan data sebagai landasan menjawab rumusan masalah atau menguji hipotesis penelitian, maka diperlukan berbagai proses pengolahan serta analisis data. Metode 
analisis data pada penelitian ini menggunakan Analisis Sidik Ragam (Ansira) atau Uji F. Analisis data Ansira bertujuan untuk menguji hipotesis tentang pengaruh faktor perlakuan terhadap keragaman data percobaan.

\section{HASIL DAN PEMBAHASAN}

\subsubsection{Pengolahan Minyak Goreng Kelapa}

Pengolahan minyak goreng kelapa menggunakan metode tradisional atau pemanasan. Metode ini sering digunakan dimasyarakat khususnya di Kabupaten Sambas karena alat dan bahan yang digunakan lebih mudah didapat. Tahap pengolahan minyak goreng kelapa pada penelitian ini yaitu daging buah kelapa tua sebanyak $5 \mathrm{Kg}$ dicuci bersih kemudian diparut untuk memudahkan pemisahan santan kelapa dengan ampasnya. Hasil parutan tersebut ditambahkan air dingin sebanyak 5 liter. Santan kelapa akan terlarut bersama air dingin sehingga proses penyaringan santan kelapa lebih mudah dan hasil saringan santan menjadi lebih banyak. Santan kelapa hasil penyaringan ditambahkan air panas dengan konsentrasi 1 Liter air panas berbanding 3 Liter santan kelapa. Penambahan air panas berfungsi untuk memecah pati santan kelapa sehingga proses pemisahan skim dengan krim akan semakin cepat.

Tahap selanjutnya , sentan kelapa tersebut didiamkan selama 24 jam atau hingga santan kelapa berubah menjadi warna krim. Dari proses ini, terbentuk 2 lapisan yaitu krim pada lapisan atas dan skim pada lapisan bawah. Krim mengandung kadar minyak yang tinggi yaitu berkisar $40-60 \%$ sedangkan skim mengandung minyak sangat rendah dan terdiri dari banyak air sehingga bagian krim yang digunakan dalam pengolahan minyak goreng kelapa.

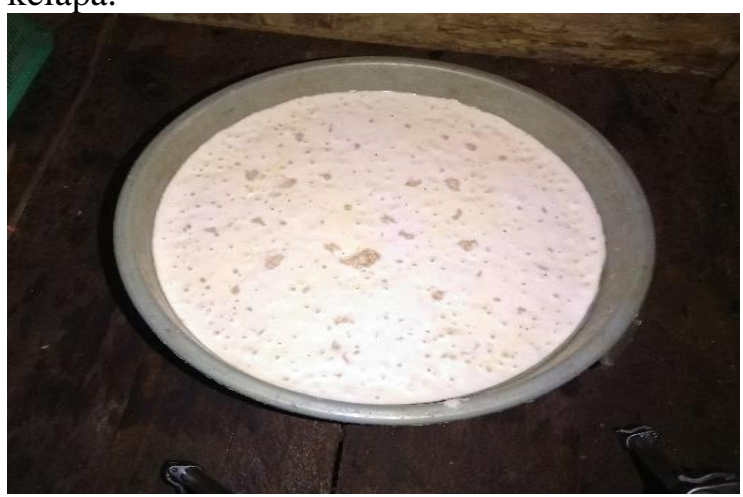

Gambar 1. Krim

Krim yang telah dipisahkan selanjutnya dimasak pada suhu $180^{\circ} \mathrm{C}$ atau hingga blondo bewarna kuning. Pada proses pemanasan, krim dipecah untuk melepas minyak yang terikat dalam krim. Hasil pemecahan krim akan terbentuk padatan yang disebut dengan blondo dan minyak goreng kelapa. Selanjutnya dilakukan penyaringan untuk memisahkan blondo dengan minyak goreng kelapa.

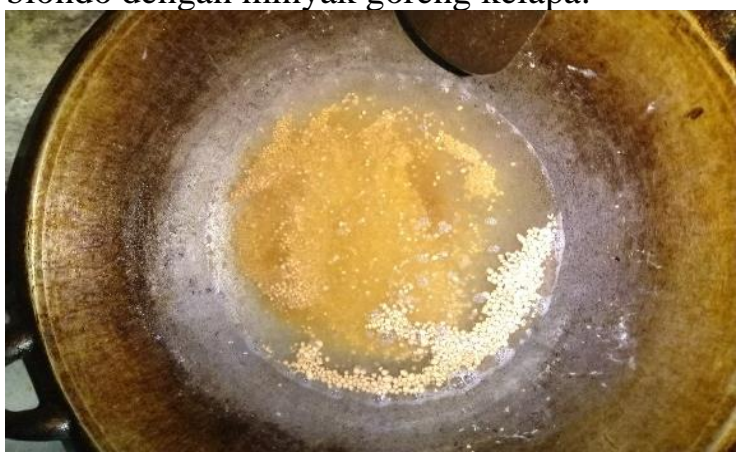

Gambar 2. Minyak Goreng Telah Matang

Minyak yang dihasilkan secara tradisional berwarna agak kekuningan. Hal ini karena suhu saat pemanasan yang tinggi, selain itu antioksidannya mengalami kerusakan dan kandungan asam lemak rantai sedang juga banyak yang hilang (Baswardojo, 2005 dalam Tembuasa 2018). Antioksidan didefinisikan sebagai senyawa yang dapat menunda, memperlambat dan mencegah proses oksidasi lipid (Muray, 2009 dalam Parwata, 2016). Akibat dari rusaknya antioksidan saat pengolahan mengakibatkan meningkatnya kadar asam lemak bebas pada minyak goreng. Semakin tinggi kadar asam lemak bebas menyebabkan penurunan kualitas dari minyak goreng tersebut. Dari penjelasan di atas, diperlukan antioksidan tambahan pada pengolahan minyak goreng kelapa untuk meningkatkan kualitasnya.

Antioksidan tambahan yang digunakan dalam pengolahan minyak goreng menggunakan rimpang kunyit. Pada penelitian ini, pengolahan minyak goreng kelapa mengunakan tiga perlakuan. Perlakuan pertama tanpa penambahan kunyit, perlakuan kedua penambahan kunyit sebanyak \pm 3 gram sewaktu titik akhir pemanasan dan perlakuan ketiga penambahan kunyit sebanyak \pm 3 gram sewaktu minyak goreng pada suhu ruang. Kunyit yang digunakan berumur 8-12 bulan dengan warna rimpang bewarna orange tua. Penggunaan rimpang kunyit pada pengolahan minyak goreng kelapa sangat efektif karena kunyit lebih diserap tubuh apabila dikonsumsi bersamaan dengan minyak karena bersifat Lipophilic (bekerja baik dengan lemak). 


\subsubsection{Analisis Kadar Asam Lemak Bebas Minyak Goreng Kelapa}

Asam lemak bebas atau free fatty acid (FFA) terbentuk dari hasil hidrolisis dan oksidasi minyak. Proses hidrolisis dan oksidasi minyak terjadi pada proses pengolahan, penyimpanan dan pemanfaatan minyak. Penentuan asam lemak bebas dapat dipergunakan untuk mengetahui kualitas dari minyak. Semakin tinggi kadar asam lemak bebas dalam minyak maka semakin rendah kualitas minyak tersebut (Fauziah, Saifuddin dan Ulfah, 2013).

Uji kadar asam lemak bebas pada penelitian ini menggunakan acuan SNI 01 37412013 tentang minyak goreng dengan metode titrasi asam basa. Setiap sampel uji diberikan kode yaitu ALB1 Untuk perlakuan tanpa penambahan kunyit, ALB2 untuk perlakuan penambahan kunyit waktu titik akhir pemanasan dan ALB3 untuk perlakuan penambahan kunyit waktu minyak goreng suhu ruang. Kode untuk ulangan pengujian diberikan kode U1 untuk ulangan 1, U2 untuk ulangan 2, U3 untuk ulangan 3 dan U4 untuk ulangan 4.

Tahap pengujian asam lemak bebas yaitu sampel sebanyak 10 gram ditambahkan alkohol $96 \%$ sebanyak $50 \mathrm{ml}$. Alkohol berfungsi untuk melarutkan minyak. Kemudian tambahkan indikator PP (Fenolftalein) sebanyak 3 tetes. Indikator PP berfungsi untuk menentukan titik akhir titrasi yang ditandai dengan perubahan warna menjadi merah muda saat sampel mencapai $\mathrm{pH}$ netral. Selanjutnya sampel dihomogenkan dan dititrasi dengan larutan $\mathrm{NaOH} \quad 0,1 \mathrm{~N}$ (Natrium Hidroksida) hingga berubah warna menjadi merah muda bertahan selama 30 detik. Namun sebelum larutan $\mathrm{NaOH}$ digunakan untuk titrasi, larutan tersebut harus distandarisasi terlebih dahulu menggunakan asam oksalat. Standarisasi larutan bertujuan untuk menentukan Normalitas larutan. Langkah kerja standarisasi larutan $\mathrm{NaOH} 0,1 \mathrm{~N}$ sama dengan prosedur uji kadar asam lemak bebas.

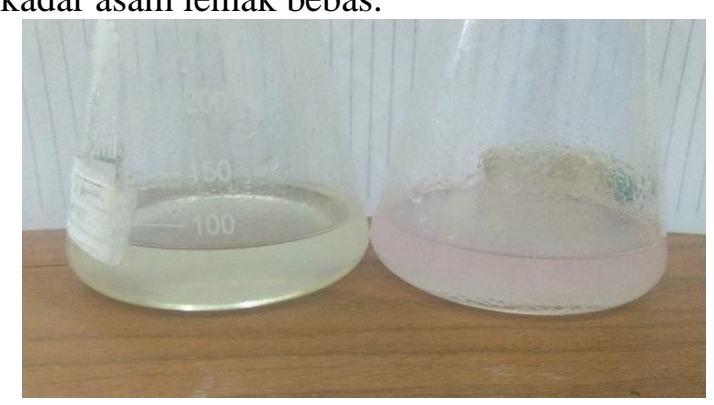

Gambar 3. Sampel Sebelum dan Sesudah Titrasi

Hasil titrasi dihitung mengunakan rumus:

$\% \mathrm{ALB}=\underline{\text { Volume titrasi } \times \mathrm{N} \mathrm{NaOH} \times \text { Berat Molekul FFA }} \times 100 \%$ Berat Sampel x 1000

Pengujian kadar asam lemak bebas dilakukan saat minyak goreng baru dan minyak goreng telah disimpan selama satu bulan dengan dua kali pengulangan setiap sampel. Pengulangan dilakuan untuk mengetahui keakuratan dalam pengujian. Adanya selisih nilai antara ulangan 1 dengan ulangan 2 dan ulangan 3 dengan ulangan 4 disebabkan eror dalam pengujian. Dari hasil uji yang didapat, setiap pengulangan tidak berbeda jauh sehingga data hasil uji dapat digunakan.

Hasil Uji Kadar Asam Lemak Bebas Kode Sampel ALB 1

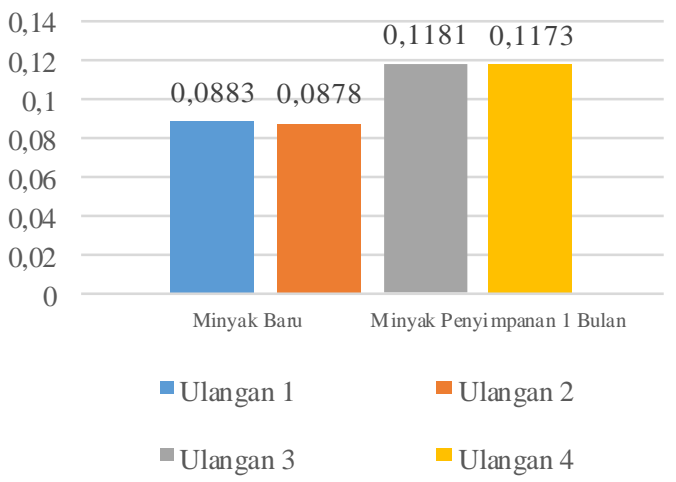

Gambar 4. Grafik Hasil Uji Kadar Asam

Lemak Bebas Kode Sampel ALB1

Hasil uji kadar asam lemak bebas pada minyak goreng kelapa baru dengan kode sampel ALB1 ulangan 1 sebesar 0,0883\% dan ulangan 2 sebesar $0,0878 \%$. Kadar asam lemak bebas ini terbentuk dari reaksi hidrolisis selama pembuatan minyak. Reaksi hidrolisis dipicu oleh adanya aktivitas air dan panas suhu tinggi yang melepas asam lemak bebas dari gliserol. Pemanasan suhu tinggi ini juga merusak senyawa antioksidan dalam minyak goreng kelapa.

Setelah disimpan selama 1 bulan, kadar asam lemak bebasnya meningkat menjadi $0,1181 \%$ untuk ulangan 3 dan $0,1173 \%$ untuk ulangan 4. Peningkataan kadar asam lemak bebas terjadi karena adanya reaksi oksidasi minyak. Reaksi oksidasi dipicu oleh minyak kontak dengan oksigen. Dengan ditambahkannya kunyit sebagai pengganti 
antioksidan yang rusak akibat pemanasan dapat menurunkan kadar asam lemak bebas. Ini dapat dilihat dari hasil uji sampel ALB2 dan ALB3 minyak baru.

Hasil Uji Kadar Asam Lemak Bebas Kode Sampel ALB 2

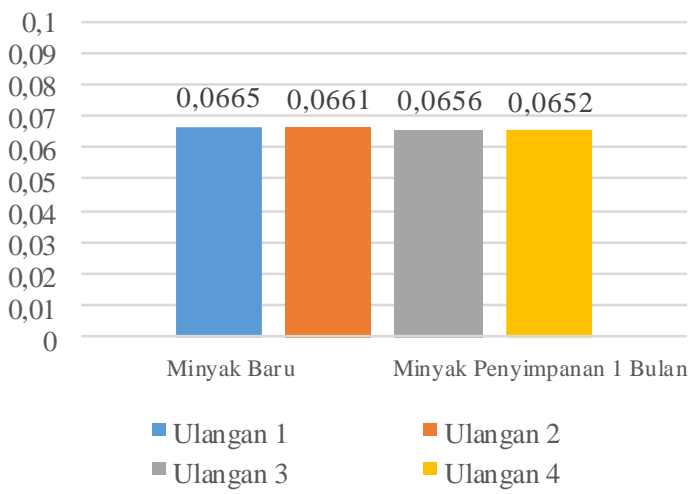

Gambar 5. Grafik Hasil Uji Kadar Asam Lemak Bebas Kode Sampel ALB2

Hasil uji kadar asam lemak bebas minyak goreng kelapa baru dengan kode sampel ALB2 ulangan 1 sebesar 0,0665\%; ulangan 2 sebesar $0,0661 \%$. Setelah disimpan selama 1 bulan, kadar asam lemak bebasnya tidak mengalami perubahan yang signifikan yaitu ulangan 3 sebesar $0,0656 \%$ dan ulangan 4 sebesar $0,0652 \%$. Berdasarkan hasil uji ini menunjukkan bahwa penggunaan rimpang kunyit dapat menggantikan senyawa antioksidan dalam minyak goreng kelapa yang rusak akibat dari proses pengolahan. Antioksidan tersebut dapat menghambat terbentuknya asam lemak bebas. Namun, dalam penggunaan rimpang kunyit diperlukan energi panas dalam waktu singkat untuk merombak pati kunyit untuk melepaskan senyawa-senyawa yang terikat di dalamnya. Dengan terurainya senyawa-senyawa tersebut sehingga kerja dari senyawa antioksidan dapat berjalan dengan baik.
Hasil Uji Kadar Asam Lemak Bebas Kode Sampel ALB 3

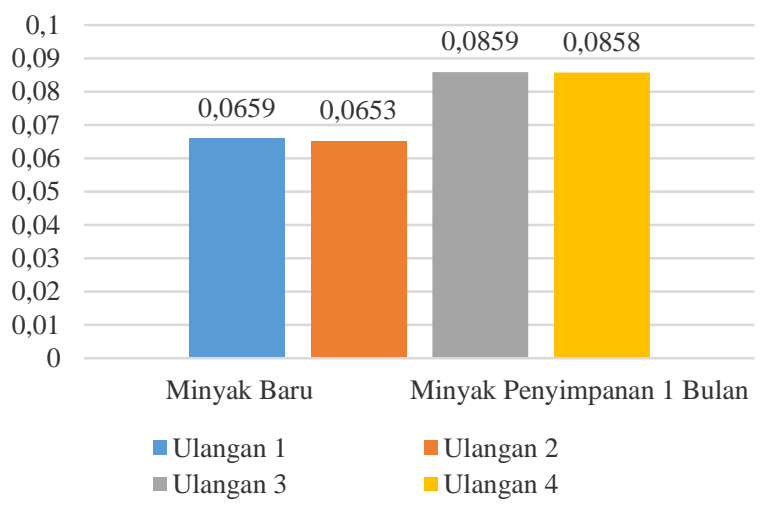

Gambar 6. Grafik Hasil Uji Kadar Asam Lemak Bebas Kode Sampel ALB3

Hasil uji kadar asam lemak bebas minyak goreng kelapa baru dengan kode sampel ALB3 pengulangan 1 sebesar 0,0659\%; pengulangan 2 sebesar $0,0653 \%$. Setelah disimpan selama 1 bulan pada kode sampel ALB3 meningkat menjadi $0,0859 \%$ untuk ulangan 3 dan 0,0858\% untuk ulangan 4 . Peningkatan ini dikarenakan senyawa antioksidan pada kunyit masih ada yang terikat oleh pati kunyit. Sehingga antioksidan tersebut hanya dapat memperlambat proses oksidasi.

Grafik hasil uji kadar asam lemak bebas minyak goreng kelapa sampel ALB1, ALB2 dan ALB3 menunjukkan kadar tertinggi terlihat pada sampel ALB1 minyak baru. Ini terjadi karena minyak goreng kelapa mengalami reaksi hidrolisis saat pembuatannya. Setelah disimpan selama 1 bulan meningkat lebih cepat dibanding sampel ALB3.Dengan ditambahkan kunyit waktu pengolahannya, sampel ALB2 dan ALB3 minyak baru mengalami penurunan kadar asam lemak bebas. Ini disebabkan senyawa antioksidan yang ditambahkan mengubah asam lemak bebas ke bentuk yang lebih setabil. Setelah disimpan selama 1 bulan sampel ALB2 tidak mengalami peningkatan kadar asam lemak bebas karena senyawa antioksidan memutus rantai oksidasi minyak dan mengubahnya ke bentuk yang lebih stabil. Namun pada sampel ALB3 mengalami peningkatan. Peningkatan kadar asam lemak bebas terjadi karena adanya reaksi oksidasi selama penyimpanan. 
Dari data hasil uji di atas, belum ada yang melewati batas maksimum kadar asam lemak bebas minyak goreng kelapa yang diatur oleh Standar Nasional Indonesia (SNI). Kadar asam lemak bebas yang diperbolehkan sesuai yang dercantum dalam SNI 01- 3742- 2002 tentang standar mutu minyak goreng yaitu $0,30 \%$. Kadar tertinggi terlihat pada sampel yang tidak ditambahkan kunyit saat pengolahan yaitu sebesar $0,1181 \%$ setelah disimpan selama 1 bulan. Semakin lama penyimpan minyak goreng kelapa, maka kadar asam lemak bebasnya akan semakin tinggi karena proses oksidasi selama penyimpanan tetap berlanjut.

\subsubsection{Analisi Data}

Analisis data pada penelitian ini menggunakan uji Analisis Sidik Ragam (Ansira). Ansira bertujuan untuk menjawab hipotesis penelitian.

Tabel 2. Hasil Analisis Data Analisis Sidik Ragam (Ansira)

\begin{tabular}{|c|c|c|c|c|c|c|}
\hline \multirow{2}{*}{$\begin{array}{l}\text { Sumber } \\
\text { Keraga } \\
\text { man }\end{array}$} & \multirow{2}{*}{$\begin{array}{l}\text { De } \\
\text { raj } \\
\text { at } \\
\text { Be } \\
\text { ba } \\
\text { s }\end{array}$} & \multirow{2}{*}{$\begin{array}{l}\text { Juml } \\
\text { ah } \\
\text { Kua } \\
\text { drat }\end{array}$} & \multirow{2}{*}{$\begin{array}{l}\text { Kua } \\
\text { drat } \\
\text { Teng } \\
\text { ah }\end{array}$} & \multirow{2}{*}{$\begin{array}{l}\text { F } \\
\text { Hitu } \\
\text { ng }\end{array}$} & \multicolumn{2}{|c|}{$\begin{array}{c}\mathbf{F} \\
\text { Tabel }\end{array}$} \\
\hline & & & & & $\begin{array}{l}5 \\
\%\end{array}$ & \\
\hline $\begin{array}{l}\text { Perlakua } \\
\mathrm{n}\end{array}$ & 2 & $\begin{array}{l}0,002 \\
9\end{array}$ & $\begin{array}{l}0,001 \\
45\end{array}$ & $\begin{array}{l}10,3 \\
571 \\
\end{array}$ & $\begin{array}{l}4, \\
26\end{array}$ & $\begin{array}{l}8, \\
02 \\
\end{array}$ \\
\hline Galat & 9 & $\begin{array}{l}0,001 \\
3\end{array}$ & $\begin{array}{l}0,000 \\
14 \\
\end{array}$ & & & \\
\hline Total & 11 & & & & & \\
\hline
\end{tabular}

Dari data tersebut menunjukkan bahwa F Hitung lebih besar dari F Tabel pada taraf $5 \%$ dan $1 \%$, sehingga disimpulkan bahwa perlakuan percobaan waktu penambahan kunyit dalam pembuatan minyak goreng kelapa berpengaruh sangat nyata terhadap kadar asam lemak bebas minyak goreng kelapa

Hasil Ansira pada penelitian ini menunjukkan nilai $\mathrm{F}$ Hitung sebesar 10,3571 sedangkan nilai $\mathrm{F}$ Tabel taraf 5\% sebesar 4,26 dan F Tabel taraf $1 \%$ sebesar $8,02 \%$. Nilai uji Ansira ini menunjukkan F Hitung lebih besar dari nilai $\mathrm{F}$ Tabel pada taraf uji $5 \%$ dan $1 \%$. Dengan demikian, $\mathrm{H}_{1}$ (hipotesis penelitian) diterima pada taraf uji $1 \%$. Sehingga disimpulkan bahwa waktu penambahan rimpang kunyit berpengaruh sangat nyata terhadap kadar asam lemak bebas dalam minyak goreng kelapa.
Awal proses asam lemak bebas dihasilkan melalui proses pemecahan oksidasi. Namun, pada tahap selanjutnya asam lemak bebas dihasilkan dari proses hidrolisis yang disebabkan karena adanya air. Minyak yang digunakan dalam proses memiliki resiko besar dalam terbentuknya asam lemak bebas karena adanya perlakuan panas dengan temperatur yang tinggi menyebabkan kandungan asam lemak bebas tinggi (Pramitha, 2012). Pernyataan ini sesuai dengan data yang didapat dari penelitian ini. Tingginya kadar asam lemak bebas pada minyak goreng kelapa yang tidak ditambahkan kunyit dikarenakan senyawa antioksidan di dalamnya rusak akibat pemanasan suhu tinggi dengan waktu yang cukup lama dan penyimpanan minyak goreng kelapa. Senyawa antioksidan ini berfungsi untuk menunda, memperlambat dan mencegah oksidasi minyak.

Minyak goreng kelapa yang ditambahkan kunyit waktu titik akhir pemanasan tidak mengalami peningkatan kadar asam lemak bebas setelah disimpan selama 1 bulan. Ini karena kunyit memerlukan energi panas yang tinggi dalam waktu singkat untuk merombak pati dan melepas senyawa-senyawa yang terikat di dalamnya. Dengan terlepasnya senyawa tersebut sehingga kerja senyawa antioksidan kunyit berjalan dengan baik. Sedangkan penambahan kunyit pada suhu ruang hanya dapat menghambat proses hidrolisis minyak karena antioksidan kunyit hanya sedikit yang dapat dimanfaatkan sehingga proses oksidasi selama penyimpanan tetap berlangsung. Dari hasil ini terlihat jelas bahwa adanya perbedaan yang sangat nyata pada setiap perlakuan percobaan.

\section{KESIMPULAN}

Waktu penambahan kunyit di titik akhir pemanasan pada pembuatan minyak goreng kelapa adalah waktu yang terbaik karena dapat menurunkan dan menghambat terbentuknya asam lemak bebas.

\section{REFERENSI}

Anam, M, S. 2016. Jenis Data Penelitian. Program Pascasarjana Program Studi Pendidikan Olahraga. Universitas Negeri Malang. Malang. 
Anggun, C. 2012. Budidaya Tanaman Kunyit (Curcuma domestika Val) dan Khasiatnya Sebagai Obat Tradisional di PT. Indmira Citra Tani Nusantara Jl. Kaliurang KM. 16,3 Seleman Yogyakarta. Program Diploma III Agribisnis Agrofarmaka. Fakultas Pertanian. Universitas Sebelas Maret. Surakarta.

Angriani, 2014. Asam Lemak Bebas. https://www.academi.edu/1901587 8/asam-Lemak-Bebas. Akses, 25 Juni 2019.

Badan Standarisasi Nasional. 2002. SNI 01 37412002 Minyak Goreng. Badan Standarisasi Nasional.

Badan Standarisasi Nasional. 2013. SNI 01 37412013 Minyak Goreng. Badan Standarisasi Nasional.

Direktorat Jendral Perkebunan. 2014. Statistik Perkebunan Indonesia Komoditi Kelapa 2013-2015. Direktorat Jendral Perkebunan. Jakarta.

Dinas Perkebunan Provinsi Kalimantan Barat. 2018. Statistik Luas dan Produksi Komoditi Perkebunan Tahun 2017. Dinas Perkebunan Provinsi Kalimantan Barat.

Duni, M, F. 2009. Teori Dasar Antioksidan. Universitas Respati Yogyakarta.

Fauziah., Saifuddin, S, dan Ulfah. 2013. Analisis Kadar Asam Lemak Bebas dalam Gorengan dan Minyak Bekas Hasil Gorengan Makanan Jajanan di Workshop UNHAS. Fakultas Kesehatan Masyarakat. Universitas Hasanuddin. Makasar.

Glory, D, V. 2018. Analisis Asam Lemak Bebas, Peroksida dan Sensori pada
Penggunaan Berulang Minyak Goreng Oleh Pedagang Makanan Gorengan Di Kampus Universitas Lampung. Fakultas pertanian. Universitas lampung. Bandar lampung.

Hanafiah, K, A. 2008. Rancangan Percobaan. Rajagravindo Persada. Jakarta.

Hartati, S, Y dan Balitro. 2013. Khasiat kunyit Sebagai Obat Tradisionaldan Manfaat Lainnya. Warta Penelitian dan Pengembangan Tanaman Industri. Jurnal Puslitbang Perkebunan Vol 19 5-9.

Ketaren, S. 2008. Pengantar Teknologi Minyak dan Lemak Pangan. UIPress. Jakarta.

Ketaren, S. 2012. Minyak dan Lemak Pangan. Pengantar Teknologi. Edisi 1, Cetakkan 1. Universitas Indonesia. Jakarta.

Kumalasari, E. 2012. Analisis Asam Lemak Bebas. Jurusan Teknologi Pertanian. Universitas Hasanuddin. Makasar.

Mamuaja, C, F. 2017. Lipida. Universitas Sam Ratulangi. Unsrat Press. Manado.

Mardiatmoko, G dan Ariyanti, M. 2018. Produksi Tanaman Kelapa (Cocos nurcifera L.). Fakultas Pertanian. Universitas Pattimura. Atta Jaya. Ambon.

Nailil, A, A., Dwi, U, S dan Husna, N. 2016. Analisis Data Kualitatif dan Kuantitatif. Fakultas Sains dan Teknologi. Universitas Islam Negeri Walisongo. Semarang.

Parwata, M, O, A. 2016. Antioksidan. Kimia Terapan Program Pascasarjana. Universitas Udayana. 
Pramitha, A. R. A. 2012. Studi Kualitas Minyak Makanan Gorengan pada Pengunaan Minyak Goreng Berulang. Program Studi Ilmu Dan Teknologi Pangan. Jurusan Teknologi Pertanian. Universitas Hasanudin. Makasar.

Purba, E, R dan Martosupono, M. 2009. Kurkumin Sebagai Senyawa Antioksidan. Magister Biologi. Universitas Kristen Satya Wacana. Jurnal Prosiding Seminar Nasional Sains dan Pendidikan Sains IV, No. 3:607-621 Hal 614.

Septiani, A, P. 2014. Titrasi Asam-Basa. Program Studi Agribisnis. Universitas Muhammadiyah Purwokerto.

Sopianti, D., Herlina dan Saputra, H, T. 2017. Penetapan Kadar Asam Lemak Bebas pada Minyak Goreng. Akademi Farmasi AlFalah. Bengkulu. Jurnal Katalisator Vol 2 No. 2 2017. Hal. 102.

Sugiyono. 2013. Metode Penelitian Kuantitatif, Kualitatif dan $R \& D$. Alfabet. Cetakan ke-19. Bandung. 